\title{
潮流・海流発電 \\ Tidal and Ocean Current Power Generation
}

\author{
経塚雄 策* \\ Yusaku KYOZUKA
}

Key Words: Tidal Current Power, Ocean Current Power, Tidal Turbine, Tidal Power Test Site

\section{1. はじめに}

海流は、主に海面上を吹く風によって発生する流れであ り、地球の自転の影響によって大洋の西側で流れが強化さ れる。北太平洋では黒潮、北大西洋ではメキシコ湾流など 大洋の西側で強い定常的な流れが発生する。黒潮の流速は 速いところでは $2 \mathrm{~m} / \mathrm{s}$ 以上に達し、その強い流れは幅 100 $\mathrm{km}$ 以上にも及び、輸送する水の量は毎秒 5,000 万トンにも 達するとされている。この膨大なエネルギーの一部でも利 用して発電できれば、安定したエネルギー源となることは 想像に難くない。

一方、潮流エネルギーは太陽、地球、月などの天体運動 に基づく潮汐力によって発生し、地球の自転に伴って日変 化する非定常エネルギーである。1 日 2 回の干満、15 日周 期の大潮、小潮で表現されるように変動する流れであり、 その流れは周囲の地形に大きく依存する。例えば、最大流 速が 10 ノット $(5 \mathrm{~m} / \mathrm{s})$ と我が国で最も速い潮流で知られる 鳴門海峡については、淡路島の東側と西側における潮位差 自体は最大でも $1 \mathrm{~m}$ 程度にすぎないが、鳴門海峡をはさん で潮位が逆位相となることによって、速い流れが出現する。 潮流の変動は規則正しく起こるので長期にわたって予測可 能であり、信頼性の高いエネルギー源とみなすことができ る。

潮流発電については、現在のところ欧米、カナダにおい て研究開発が進んでいるが、特に欧州においてはスコッ トランドのオークニー島にある EMEC (European Marine

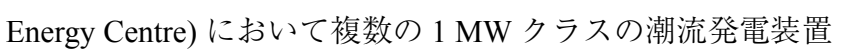
の実証実験が行われ、着実な実績を上げてきたことが商業 発電の到来を予感させていたが、2012 年 12 月に欧州委員 会 $(\mathrm{EC})$ が 2 つ UK の潮流発電プロジェクトに各 20 億円 以上の投資を決定したニュースが発表されるに及んで、い よいよそれが現実化してきた。

本報では、潮流発電装置に関する基礎的な説明を行い、
実用化が間近となっている潮流発電装置を紹介する。また、 潮流発電装置の設置法と係留法、および我が国の潮流発電 の現状と今後の課題について述べる。

\section{2. 流れの発電パワー}

流体の運動エネルギーから得られる発電パワーの理論式 は次式で与えられる。

$$
P=\frac{\rho}{2} A U^{3} \times \eta_{T}
$$

ただし、: 海水密度、: タービン面積、: 流速、: タービン効 率 $(=0.3 \sim 0.4$ 程度 $)$

この式は風力発電と同じであるが、海水の密度は空気の 約 800 倍なので、流速は小さくても大きなパワーが得られ ることになる。流速は、黒潮についてはほぼ一定值とおけ るが、潮流については時間とともに変化するので発電量も 時間によって変化する。潮流の流速を単純化して

$$
u(t)=U_{\max } \cdot \sin \left(\frac{2 \pi}{T} t\right)
$$

ただし、 $\mathrm{T}$ ：周期（通常は 12 時間 25 分）

で考えると、平均発電量は

$$
\begin{aligned}
\bar{P} & =\rho A \eta_{T} \frac{2}{T} \int_{0}^{T / 2} u^{3}(t) d t=\frac{2 \rho A \eta_{T}}{3 \pi} U_{\max }^{3} \\
& \approx 0.42 \times \frac{\rho A \eta_{T}}{2} U_{\max }{ }^{3}
\end{aligned}
$$

のように近似計算できる。

\section{3. 海流発電装置}

黒潮の規模は、流量が $3,000 \sim 5,000$ 万 $\mathrm{m}^{3} / \mathrm{s}$ 、流速は 1 〜 5 ノット $(0.5 \sim 2.5 \mathrm{~m} / \mathrm{s})$ であり、平均流速を $0.5 \mathrm{~m} / \mathrm{s}$ 、流 路幅を $250 \mathrm{~km}$ 、水深 $1,000 \mathrm{~m}$ とおいて黒潮のパワーを計算 


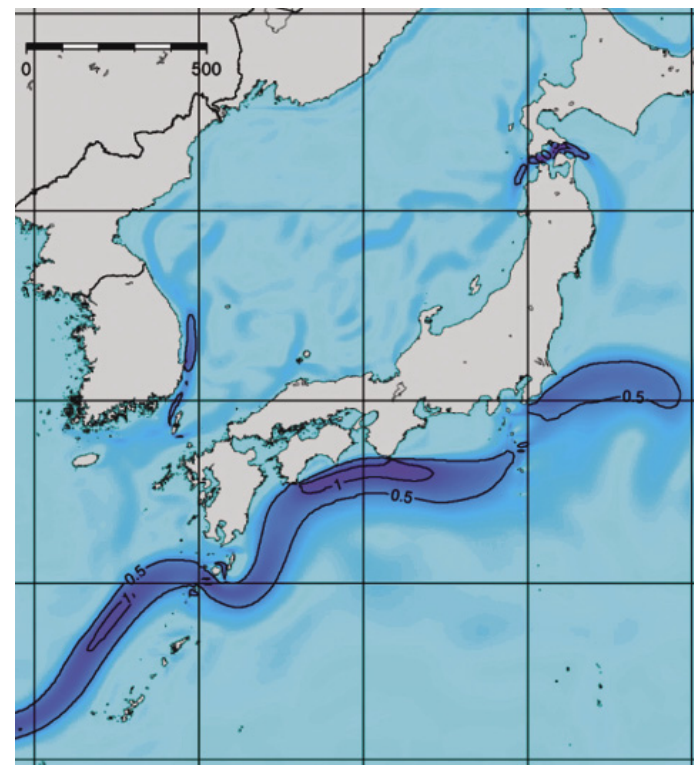

Fig.1 Distribution of 5 years average speed of Kuroshio by JCOPE2

すると、約 1,600 万 $\mathrm{kw}$ となる。もっと詳細には、独立行 政法人海洋研究開発機構 (JAMSTEC) が 2001 年から運用し ている数值海洋モデル JCOPE2 ${ }^{1)}$ が利用できる。Fig.1 は、 JCOPE2 による水面下 $5 \mathrm{~m}$ に扔ける流速デー夕から 5 年間 の平均流速值を求めたものである。この図から、平均流 速が $1 \mathrm{~m} / \mathrm{s}$ よりも大きいのは、四国から紀伊半島にかけて と、沖縄と奄美大島西方の東シナ海であることが分かる。

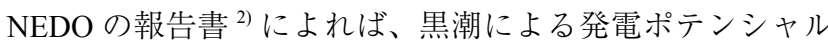
が大きいのは紀伊半島沖であって、沖合固定型かつ離岸距 離 $30 \mathrm{~km}$ 以内の海域の発電ポテンシャルは $9 \mathrm{Twh} /$ 年、沖合 係留で離岸距離 $100 \mathrm{~km}$ までの場合には $45 \mathrm{Twh} /$ 年である。 日本の総電力量は約 $1000 \mathrm{Twh} /$ 年であるので、単純計算で はあるが、黑潮発電によって約 $1 \sim 4.5 \%$ の電力が賄える ことになる。

黒潮は、数年毎に大蛇行と呼ばれる流路の変動を引き起 こすが、場所と期間を選べば、ほぼ定常流と考えても良い ので安定した発電が行える。これが黒潮の最大の利点であ る。そのため、過去にもいくつかの発電装置が考案された が、実海域での実験まで至った例はない。最近になって、 実用化を目指した研究開発が進行中である。

Fig.2 は、平成 23 年度の NEDO プロジェクトで採択され たもので、IHI、東芝、東大などのグループによる海洋中層 に㧍ける浮遊式黑潮発電装置 ${ }^{3)}$ の CG である。この装置は、 1 対のプロペラ式タービンによってトルクバランスをとり、 タービンを繋ぐ水中翼の浮力㧍よび揚力と係留索のつり合 いによって深度制御が可能となっていることである。また、 Fig.3 は、沖縄科学技術大学院大学で実施中のシーホース. プロジェクト ${ }^{4)}$ の CG であり、2012 年にタービン直径約 2 $\mathrm{m}$ の模型を用いた実海域実験が行われた。

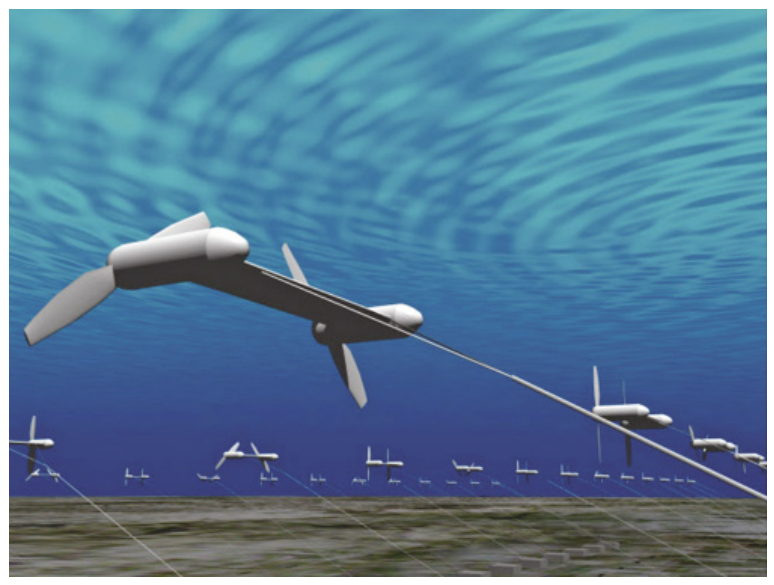

Fig.2 Floating ocean current power system by IHI, Toshiba, U. of Tokyo (CG)

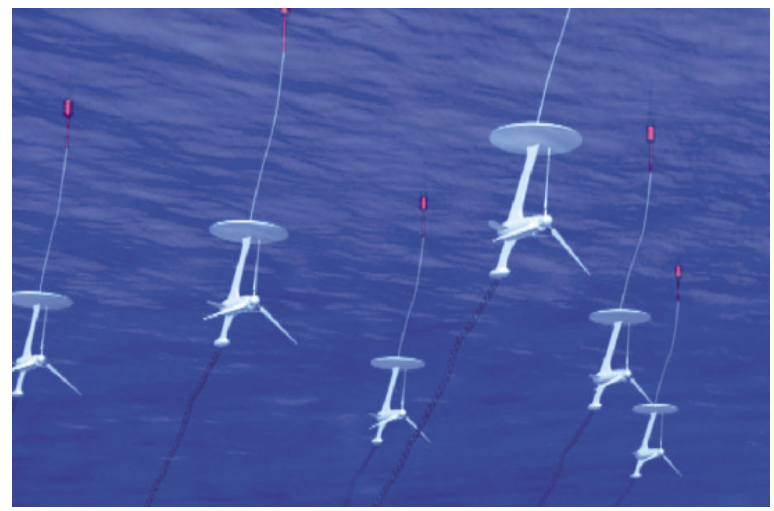

Fig.3 Seahorse project by Okinawa Inst. Sci. \& Tech. (CG)

\section{4. 潮流発電の現状}

\section{1 水車の形式}

潮流発電装置は、原理としては風車と同じであるが、海 中に設置されるため現時点でも多くの形式、タイプの水車 が提案されている段階である。水車の形式としては、揚力 型、抗力型、混合型などがある。揚力型は、プロペラの断 面が翼形をしていてその揚力を利用するものであり、一般 に高速回転し、エネルギー変換効率が高いものである。抵 抗型は、流れが物体に当るときの抵抗を利用するものであ り、古くから使われてきた水車はこのタイプである。水車 が止まっているときに最もトルクが大きく、確実に水車を 回転させることができるが、反面、効率は低い。混合型は これらの両者を組み合わせたものである。

水車のタイプとしては水平軸、鉛直軸、振動翼形などが あるが、潮流は基本的に上潮、下潮によって流れの方向を $180^{\circ}$ 変えるので、それを考虑しなければならない。水平軸 水車はプロペラ型のものであるが、一般に流れ方向に合わ せて首振り角(ヨー角)を制御しなければならない。ただし、 
潮流の方向は上潮と下潮でほぼ一定なので、ヨー制御しな いで 2 枚プロペラを同軸にして用いるものもある。

鉛直軸水車の大きな特徵は、回転軸と流れが直交するこ とであり、潮流の方向は無関係で、水平軸のようにヨー制 御は必要ない。Fig.4 は、ORPC 社 ${ }^{5)}$ の鉛直軸水車であるが、 ローターはらせん翼を用いており、横置きとなっている。

振動翼形は、流れの中で翼の迎角を制御することによっ て、上下あるいは左右に振動させるものである。Stingray と呼ばれる直線翼を用いる装置は2003 年に実海域におい て $150 \mathrm{~kW}$ の発電に成功し、実用化に有力な装置とみなさ れていたが、その後、開発中止になった。振動翼形の特徵 としては、水深が小さなところにも設置可能なことであり、 Pulse Tidal $^{9)}$ は浅い河口において開発を継続しているほか、 Fig.5 は、魚のひれにヒントを得た装置で bioSTREAM ${ }^{6)}$ と 名付けられた装置である。ひれの往復動を油圧システムを 用いて発電機を回す。ひれのスパン長 $17 \mathrm{~m}$ の装置で流速 2.7 $\mathrm{m} / \mathrm{s}$ において出力 $250 \mathrm{~kW}$ という試算がある。

潮流発電装置の有力なものは現在、実海域での実証実験 中であり、発電効率とともに、長期の安定性、メンテナン スの容易さなどがテストされているが、潮流は海域によっ て水深、流速、流向、乱れなども違うので、最適な水車も

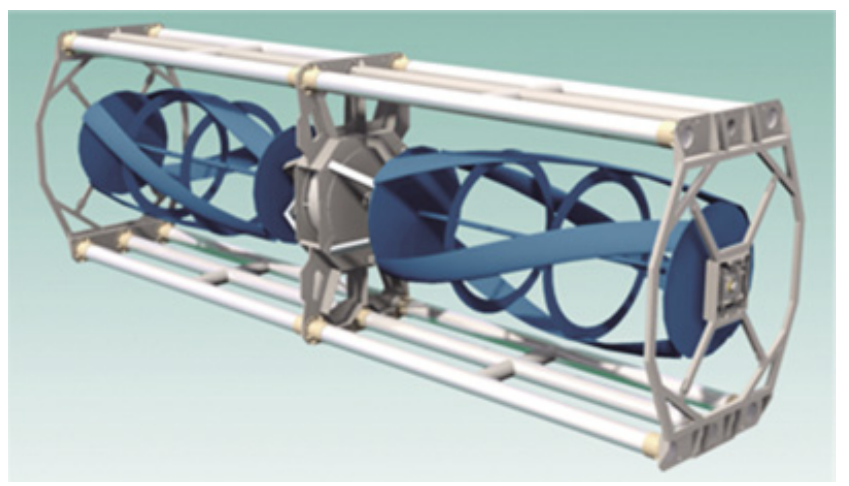

Fig.4 Vertical axis turbine by ORPC (CG)

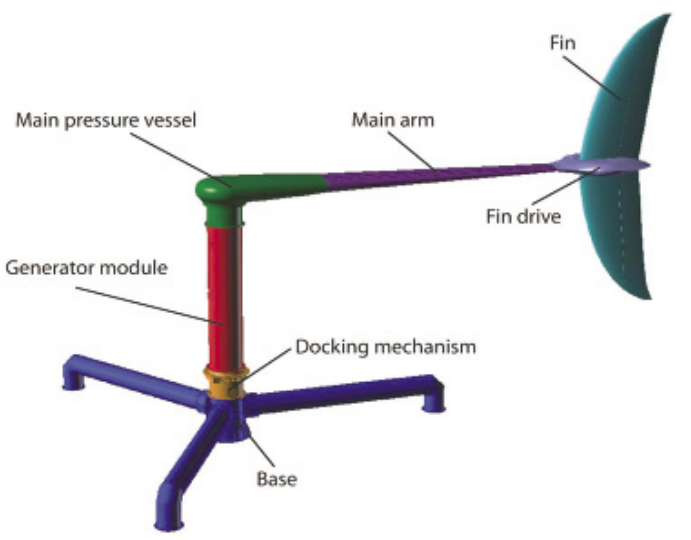

Fig.5 "bioSTREAM" oscillating wing system (CG)
海域ごとに異なることが予想される。

\section{2 設置法・係留法による分類}

潮流発電装置の設置位置は、海底上、中層、海面下な どに分けられる。海底設置型あるいは着床式の例として、 Alstrom $^{7)}$ がEMEC において実験を行っている1 MW 機の CG を Fig.6に示す。この装置は、架台と潮流発電本体が分 離可能となっているが、架台は 3 つの脚部に重量バラスト を搭載して海底に固定するものである。EMECの潮流は大 潮時に $4 \mathrm{~m} / \mathrm{s}$ 程度であり、海底地盤は岩盤あるいは礫であ ろうと思われるので現実的な設置法と思われる。着床式装 置の設置法については、水深と海底地盤の種類によって変 わるが、海底が岩盤の場合にはアンカーボルトの使用など も有効であろう。その他、Fig.7 は Tidal Energy Ltd の Delta Stream $^{8)}$ という装置であるが、 3 基の水平軸潮流発電装置を 三角形の架台によって一体化して横安定性を担保する装置 を提案している。ローター径は $15 \mathrm{~m}$ 、発電出力は $400 \mathrm{~kW} /$ 基で合計 $1.2 \mathrm{MW}$ であるが、メンテナンスの方法などにつ

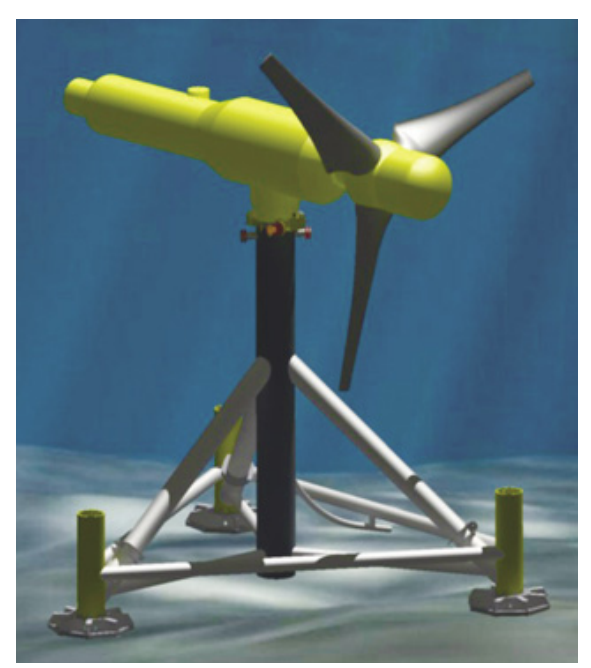

Fig.6 Bottom mount turbine by Alstrom Ltd. (CG)

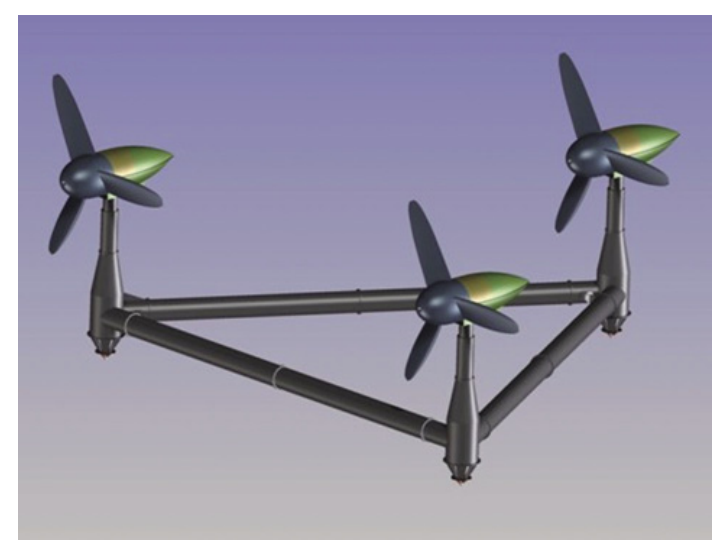

Fig.7 Delta Stream by Tidal Energy Ltd.(CG) 


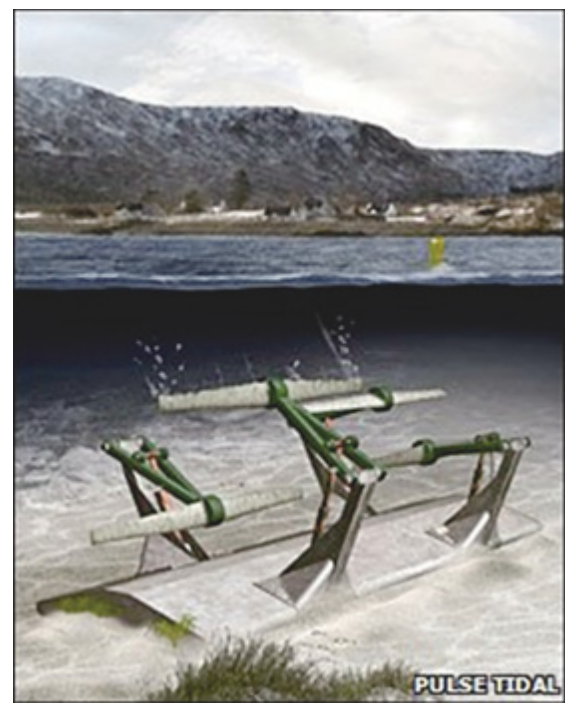

Fig.8 "Pulse Tidal” oscillating wing system in shallow water (CG)

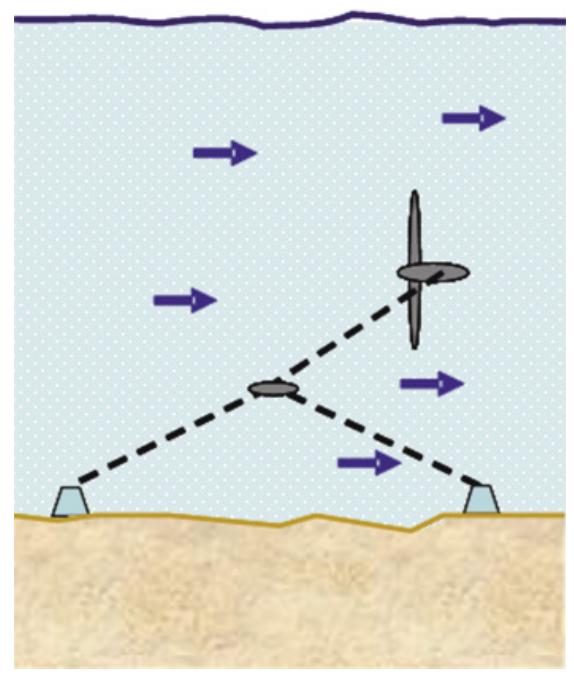

Fig.9 Floating tidal power system (illustration)

\section{いては工夫が必要かもしれない。}

Fig.8 は、Pulse Tidal ${ }^{9)}$ という着床式の振動翼装置である が、重力基礎の上に上潮用、下潮用の一対の装置を取り付 けたものである。上潮用の装置は、下潮時には稼働しない。 設置およびメンテナンスには、重力基盤ごと一体化して運 搬するようになっている。

次に、海中に鉛直パイルあるいはジャケットを組んで発 電装置を設置するためにはかなり大掛かりな海洋工事が必 要となると思われる。後述の MCT の SeaGen (Fig.13)の場 合は、水深 $30 \mathrm{~m}$ の海域において直径約 $3 \mathrm{~m}$ 、高さ約 $41 \mathrm{~m}$ の円柱状の支柱を立てたが、流速が大きな海域においてど のような工事を行ったのか、大変興味のあるところである。 潮流発電の実用化においては、装置のメンテナンスをどう

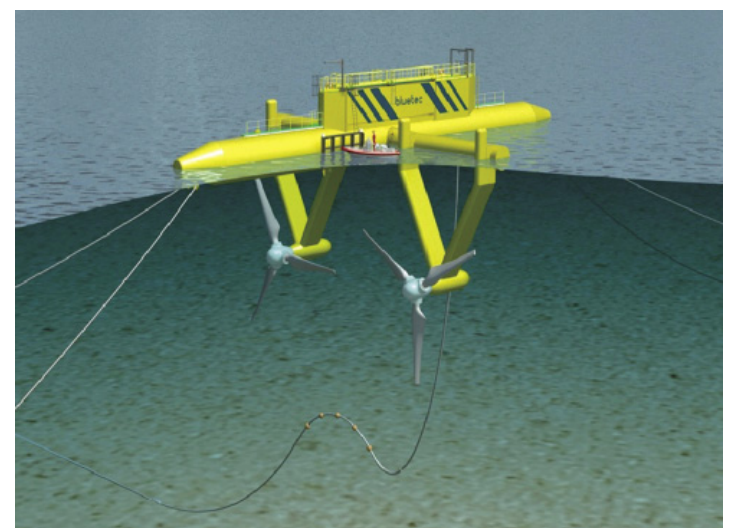

Fig.10 "BlueWater" floating system (CG)

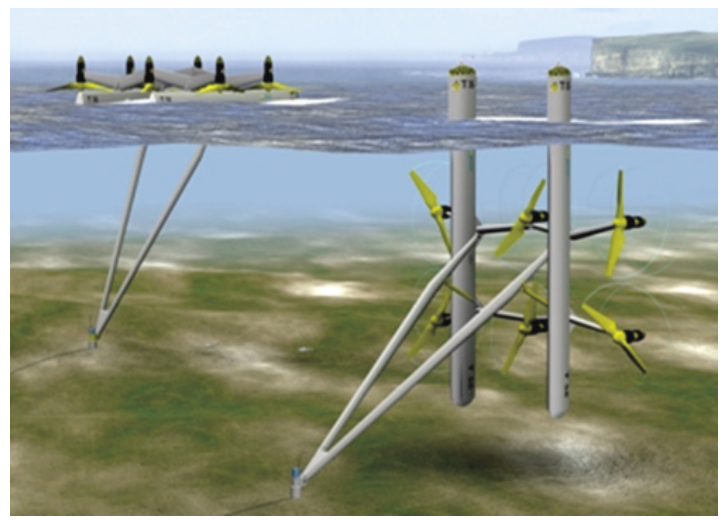

Fig.11 “TidalStream” floating system (CG)

するかは極めて重要であるが、MCT のように稼働とメンテ が同じ場所で出来ることはコスト的にも有利であると思わ れる。ただし、この方式は設置海域の水深が大きくなると コスト的に難しくなることは容易に想像できる。

Fig.9は、海の中層で浮遊させる装置のイラストであるが、 アンカー、チェーンあるいはロープで係留するものである。 “TidEL”という装置はこの方式で実海域実験まで行われた が、数年前に中止された。その理由は明確ではないが、メ ンテナンスや修理時の回収、再設置などの方法かもしれな w。

Fig.10は、BlueWater ${ }^{10)}$ の浮遊式装置の例であるが、浮体 の下に 1 対の水平軸水車がみえる。前後にチェーンあるい はロープによって係留しているので、上潮、下潮による流 向変化はタービンのピッチコントロールによっているもの と思われる。この装置は、現在、EMECにおいて実証実験 中であるが、BlueWater は船体と係留システムだけを担当し、 水車と発電システムは別会社が行うという分業制をとって いる。

Fig.11 は、TidalStream ${ }^{11)}$ の Triton 6 という浮体式で 6 ロー 夕型の装置 $(6 \mathrm{MW})$ の $\mathrm{CG}$ である。係留は浮体から延ばし 
た斜め部材による 1 点係留で、流向変化についてはパッシ ブ・ヨー制御である。また、メンテナンスについては、図 中の左側の絵のようにタービン部を水面上に出して行う計 画であるが、実証実験についてはこれからである。

\section{3 実用化間近の潮流発電装置}

Hammerfest Strom ${ }^{12)}$ は 2003 年から 2009 年までにノル ウェーの最北端近くの海峡において、Fig.12のような海 底設置形の 3 翼プロペラ式の $300 \mathrm{~kW}$ の潮流発電装置で実 海域実験を行ってきた。HS300 のプロペラ直径は $20 \mathrm{~m}$ で、 潮流の向きに応じてプロペラピッチが可変となっている。 最大流速 $2.5 \mathrm{~m} / \mathrm{s}$ の潮流中での平均出力は $80 \mathrm{~kW}$ であり、 2003 年 9 月に世界で初めて、地元の電力網に接続された。 この後継機で、実用直前機として直径 $30 \mathrm{~m}$ 、出力 $1 \mathrm{MW} の$ HS1000がある。HS1000は2011年12月にEMECに設置され、 実海域試験を行っている。なお、Hammerfest Strom は2012 年 4 月に ANDRITZ HYDRO Hammerfest となったが、2012 年末に Scottish Power Renewable が欧州委員会から受注した Islay 海峡における $20.7 \mathrm{M} €$ （約 23 億円）の $10 \mathrm{MW}$ の潮流 発電プロジェクトに採用された。今後、2013 年から 2015 年にかけて Islay 海峡において 10 基の HS1000を設置して 世界初となる潮流発電ファームを構築する予定である。

Fig.13は、イギリスの Marine Current Turbines (MCT) ${ }^{13)}$ と呼ばれる潮流発電装置で、海中に支柱を立てて、稼動中 は水中に、メンテナンス時には空中に出るような昇降機能 を備えたプロペラ式潮流発電装置である。1999年から 2006 年までの Seaflow Projectでは直径 $11 \mathrm{~m}$ の 2 翼ローターを用 いて、300 KW の実証実験に成功したが、Phase-2の SeaGen Project では、ツインローター方式で 2008 年 5 月に $1.2 \mathrm{MW}$ $(600 \mathrm{~kW} \times 2)$ の発電に成功した。設置場所は、北アイルラ ンドの Strangford 湾の湾口で、大潮時の平均最大流速は 3.7 $\mathrm{m} / \mathrm{s}$ であった。水深 $30 \mathrm{~m}$ ほどの海域に直径約 $3 \mathrm{~m}$ 、高さ約 $41 \mathrm{~m}$ の支柱を立て、上下可動の水平部材上に 2 基の発電装 置を搭載している。ローター直径は $16 \mathrm{~m} 、$ ピッチコントロー ルとなっている。なお、MCT も2012 年 4 月から Siemens Ocean \& Hydro Business の一部となっている。2012 年末に 欧州委員会から Kyle Rhea Tidal Turbine Array Project として 採択され、18.4 M€（約 21 億円）を得た。計画では、2015 年から商用発電を行う予定である。

\section{4 我が国の潮流発電装置}

我が国では、1983 年から 1988 年まで 3 期にわたって 日本大学の木方靖二教授のグループが来島海峡において 潮流発電実験を行い、世界で初めて潮流発電に成功した。 Fig.14 は、1987 年からの第 3 期で用いられた海底設置型の ダリウス形水車 ${ }^{14)}$ であり、3 枚の翼は起動トルク対策のた めに軽量化され、カーボン FRPで製作された。水車の下に 増速比 1:9の増速機があり、その下に 3 相同期発電機 (AC200 $\mathrm{V}, 5 \mathrm{~kW})$ が置かれた。第 3 期実験は、約 2 年間にわたって

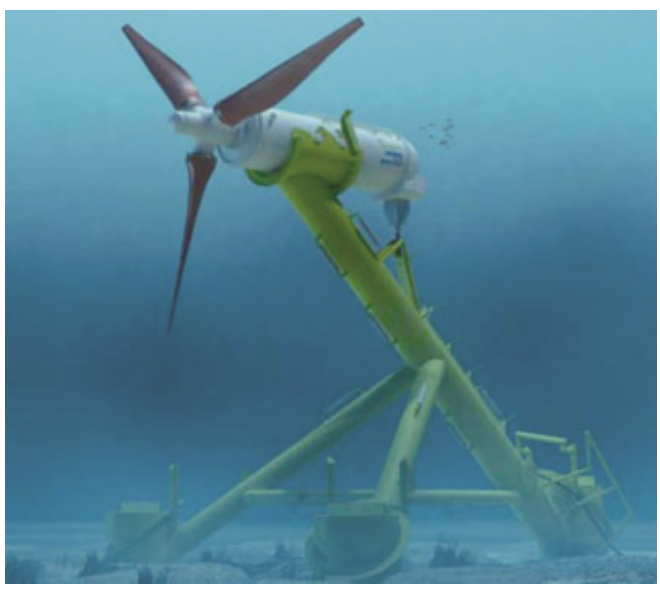

Fig.12 HS1000 by ANDRITZ HYDRO Hammerfest (CG)

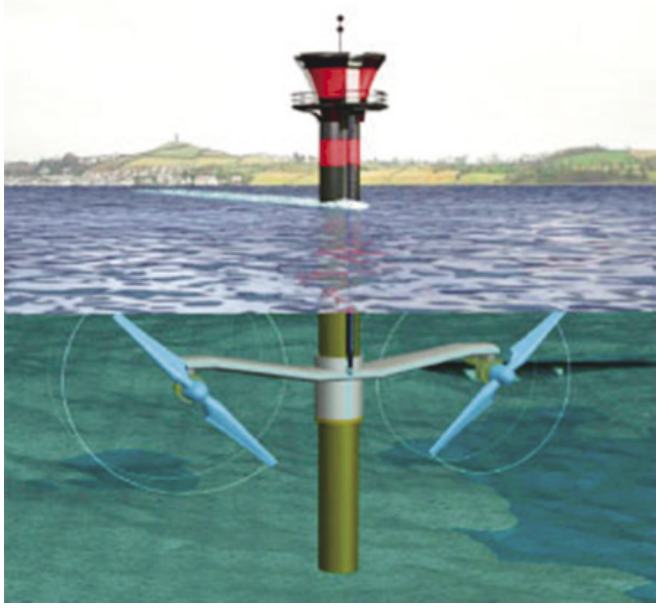

Fig.13 SeaGen Project device by MCT (CG)

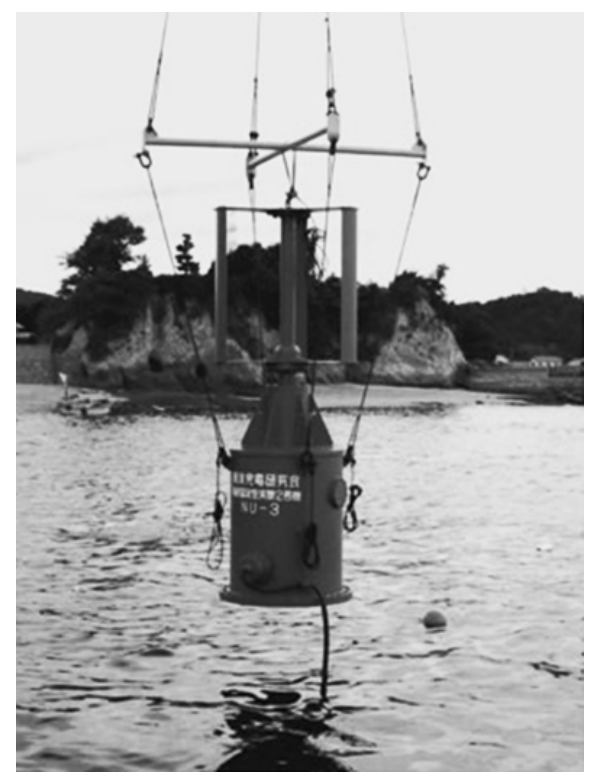

Fig.14 Darrieus turbine system by Nihon Univ. 


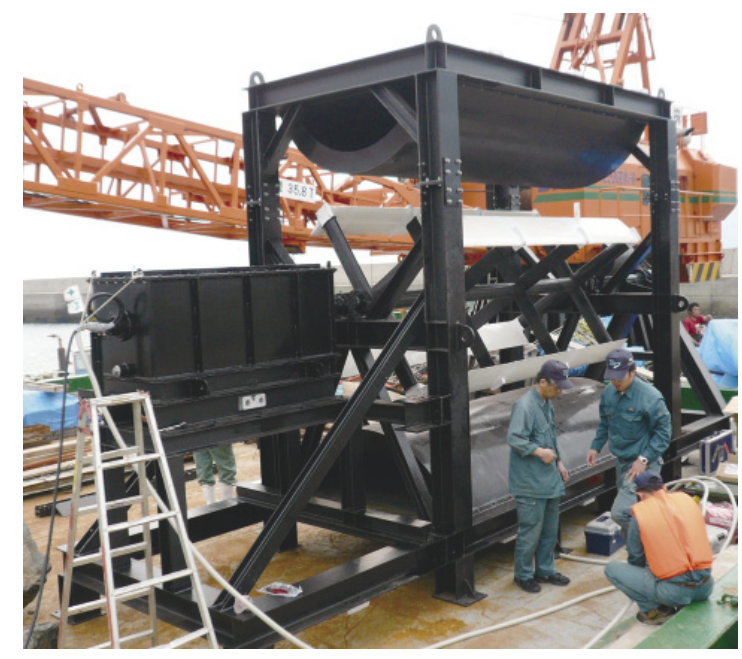

Fig.15 Darrieus turbine system with the appendage by FELCO and Kyushu Univ.

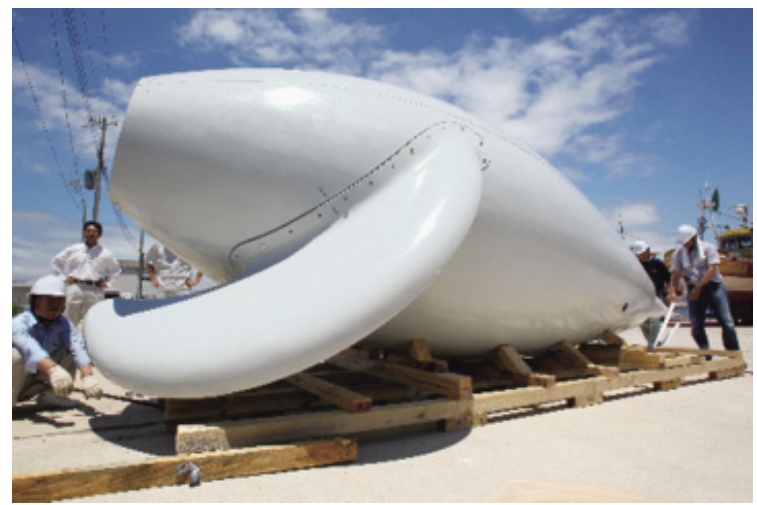

Fig.16 "Tuna Turbine" by NOVA Energy

行われ、発電効率は最大で 0.55 という非常に高い結果を得 た。また、発電量の経時変化や海洋生物による水車への影 響などの調查も行われた。この先駆的な研究は、その後の 社会の経済環境の変化により継続できなかったが、この実 海域での成功事実は重く、その後の日本大学拈よび海上保 安庁 ${ }^{15}$ 、新日鉄 ${ }^{16)}$ による潮流発電の研究でもダリウス形水 車が採用されている。

Fig.15は、九州大学と西日本流体技研が開発した増速器 付ダリウス・サボニウス水車であり、ダリウス水車は直径 $1.7 \mathrm{~m} 、$ スパン $3 \mathrm{~m} 、 4$ 枚翼であり、サボニウス水車は直径 $0.85 \mathrm{~m}$ 、スパン $1 \mathrm{~m}$ である。また、ダリウス水車の両側に 円弧状の増速器を付けることによって流速を上げる工夫を 行った。この水車は、長崎県平戸市の生月大橋の橋脚の横 に 2012 年 8 月から 12 月まで設置され、約 3 か月の発電実 験を行った。最大発電量は約 $800 \mathrm{~W}$ であったが、発電効率 としては期待值を下回る結果となった。

Fig.16は、株)ノ゙ァエネルギーが開発中のマグロタービ

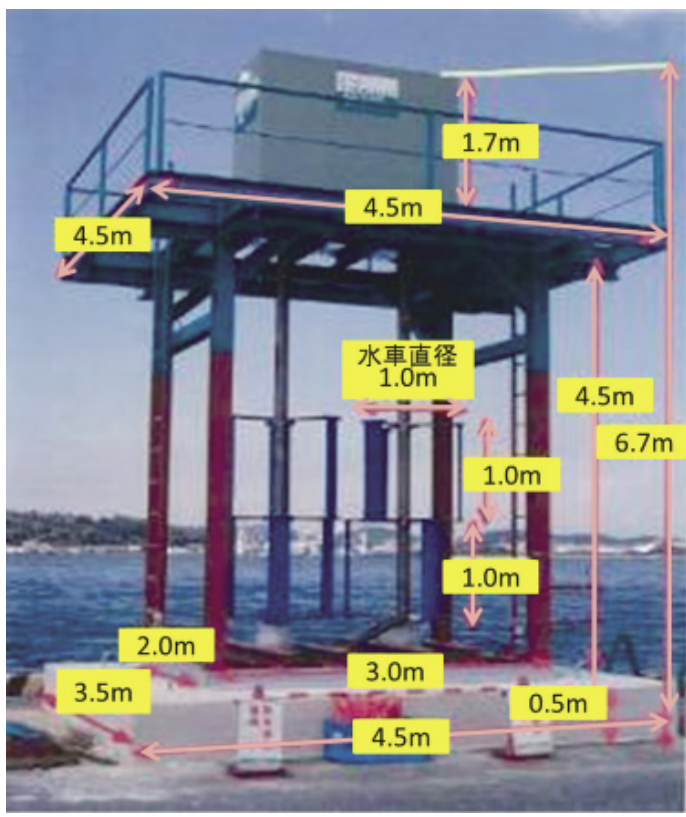

Fig.17 Twin vertical axis turbine by Kitakyushu City and Kyushu Tech. Inst.

ン ${ }^{17)}$ の写真である。同社のホームページによれば、全長 $6 \mathrm{~m} 、$ 直径 $3 \mathrm{~m}$ で出力は $10 \mathrm{~kW}$ である。2010 年に淡路島の近くで 実海域実験を行っていたが、12月にタービン 1 機の流出事 故を起こした。ただし、現在も開発を継続中であると思わ れる。

Fig.17 は、北九州市と九州工業大学が関門海峡において 実施した潮流発電装置 ${ }^{18)}$ の陸上写真である。直径㧍よびス パン長が $1 \mathrm{~m}$ のダリウス水車を 2 段に重ね、それと逆方向 に回転する 1 対のダリウス水車を用いて、1 台の相反転式 発電機を回すものである。2012 年 3 月から 1 年間の実験を 行った。

以上が、2011 年以前から行われていた主な研究開発であ るが、2011 年 3 月に発生した東日本大震災と東京電力福島 第 1 原発事故によって状況は激変してしまったと言っても 過言ではない。

「海洋エネルギー」が、2011 年度から NEDO の技術開発 対象となったため、海流・潮流発電に関する支援が始まっ た。平成 23 年度については、

A) 東大、IHI、東芝、他による「海流発電システム」

B) 川崎重工業、沖縄電力による「潮流・海流発電システム」

平成 24 年度の追加分については

C) 三井海洋開発の「海洋エネルギー発電システム実証研究」

D) 佐世保重工、東大、九大の「油圧式潮流発電」

E) ナカシマプロペラ、五洋建設、広島工大の「潮流発電」 の 5 つのプロジェクトが採択された。

A) は Fig.2で述べたものであり、B) は Fig.18の川崎重 工による潮流発電装置の開発である。直径 $18 \mathrm{~m}$ の 3 翼プ 


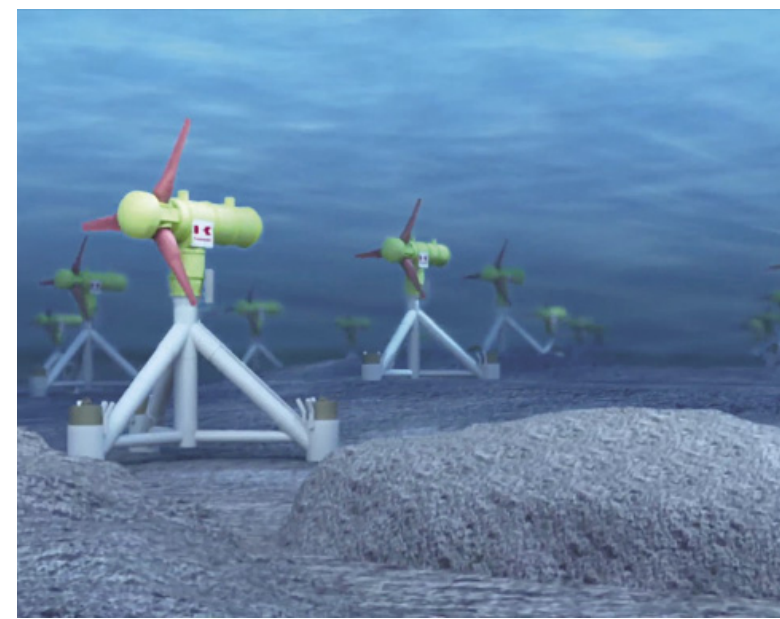

Fig.18 Tidal power generators by Kawasaki Heavy Industry (CG)

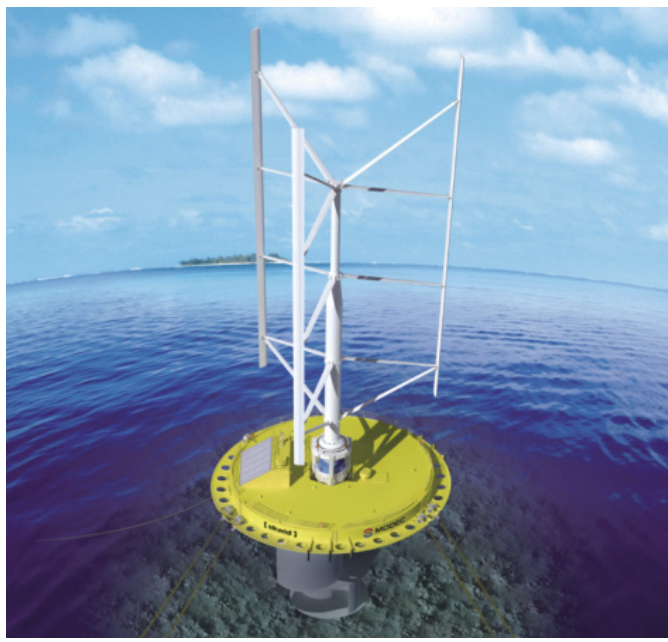

Fig.19 Skwid system by MODEC(CG)

ロペラ型でピッチとヨー・コントロールで定格出力 $1 \mathrm{MW}$ となっている。採択時の計画では、沖縄電力(株などと沖縄 海域において潮流発電の実証実験を予定していたが、同海 域には適地が見つからず別海域での実施を検討中と聞く。 なお、この装置は2013 年から EMECで実証試験を予定し ていたが、年内に実施されたというニュースはない。この 分野ではベンチャー企業が多い中で、川崎重工のような大 手企業の参入は国際的にも注目されている。

C) は、Fig.19のような洋上風力と潮流のハイブリッド 発電装置であるが、NEDO からは潮流に対して支援を受け た。ダリウス風車とサボニウス水車が同軸で互いに反対方 向に回転する機構になっており、その間に定格出力 $500 \mathrm{~kW}$ の発電機が入っている。一般に、ダリウス風車は起動卜ル クが小さいという久点があるが、それをサボニウス水車に よって解消できることが大きな特徵である。2013 年 10 月
油圧連結潮流発電システムコンセプト

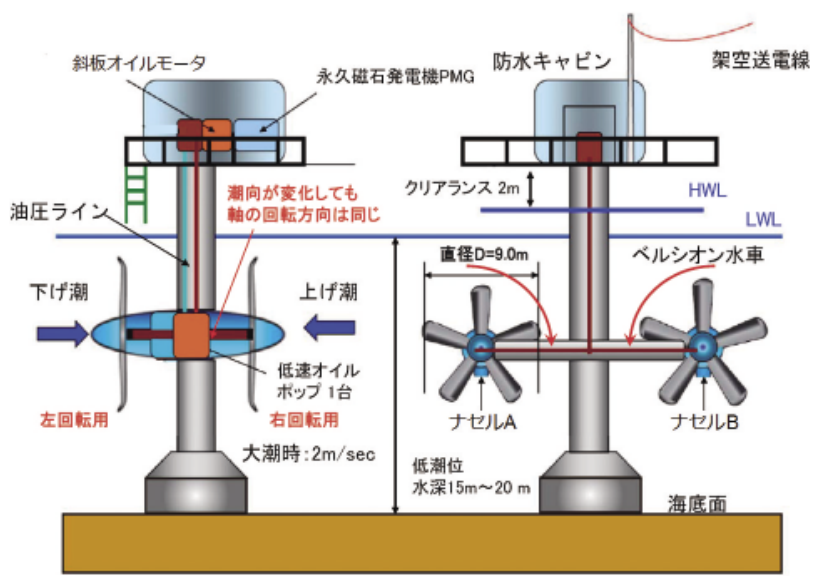

Fig.20 Oil pressure tidal power system by SSK, U. of Tokyo, Kyushu Univ. (CG)

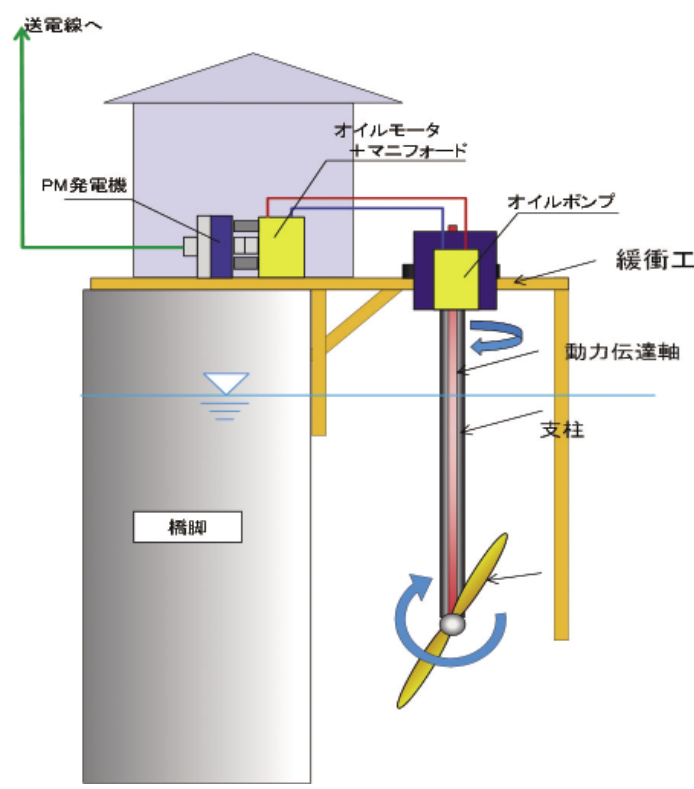

Fig.21 Tidal power system using bridge pier by Nakashima Propeller, Penta-Ocean Construction, Hiroshima Inst. Tech. (CG)

にフルスケールの実証機が佐賀県唐津市沖に設置される予 定であったが、瀬戸内海の造船所からの海上輸送中に水車 を落下する事故により約半年間の延期を余儀なくされた。

D) は、Fig.20のように重力式パイルによって 1 対の水平 軸潮流発電装置を支えるものである。水車は、前後方向に 1 対のベルシオン型ロータを持ち、ヨー角は固定となって いる。水車の動力を油圧ポンプによって、水面上のデッキ に置かれた発電システムを駆動する方式である。設置海域 としては長崎県五島市となる予定である。

E) は、Fig.21に見られるように既存の橋脚を利用して潮 流発電を低コストで行うプロジェクトである。水車は水平 


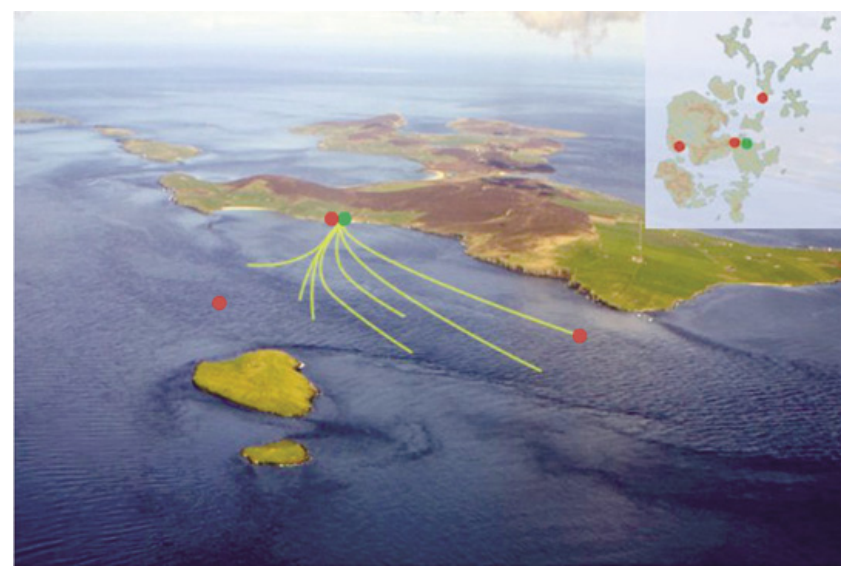

Fig.22 Tidal power site of EMEC in Orkney Islands

軸を用いるようであるが詳細については不明である。設置 海域は、瀬戸内海に多数存在する橋脚を想定しており、適 地は多いとのことである。

\section{5 実証実験フィールド}

潮流発電の実用化のためには実海域で実際に発電して実 績を示すことが必要である。そのためには実海域の実験 場が必要であるが、それを個別のプロジェクトごとに見つ けるのはいろいろな面で非効率であることから、2003 年 にスコットランドの北方の Orkney 諸島に European Marine Energy Centre Ltd ${ }^{19)}$ が設立され、波浪発電と潮流発電の研 究開発が始まった。潮流実験フィールドはEday 島にあり、 大潮時の平均最大流速は $3.7 \mathrm{~m} / \mathrm{s}$ である。 EMEC が提供する のは設置場所 (バース)、電源ケーブル、情報ケーブル、陸 上の計測小屋、各種の海洋情報、設置工事の手配などであ るが、装置の設置を申請しても装置の安全面の審査などが あり、実際に実験をするまでは敷居が高いようである。現 在、Fig.22にあるように8つのバースで有力な装置が実証 実験を行っているが、川崎重工は既にそのひとつを確保し ており、近日中に実験を行う予定である。

我が国でも、EMECの様な実証実験フィールドを保有す ベしという声が数年前から高まっていたが、それを受ける 形で平成 25 年 3 月に内閣官房総合海洋政策本部から「海洋 再生可能エネルギー実証フィールドの要件の公表及び公募 について」が発表された。それによれば、潮流を含む 5 種 類の海洋エネルギーについて、実証実験フィールドを整備 することとなり、そこが満たすべき環境条件やその他の条 件が明示された。第 1 次の募集締め切りが平成 26 年 2 月末 となっており、現在、複数の県で調査が進行中である。特 に、我が国の海域においては漁業権が最優先となっており、 海洋エネルギーを実用化するためには漁業者との連携は欠 かせない。早ければ、平成 26 年度中にも実証実験フィール ドが整備・開放されて、潮流発電装置の研究開発が進むこ
とを期待したい。

\section{5. 実用化に向けて今後の課題}

今後の潮流発電の開発と実用化に向けてアメリカのグ ループが発表したロードマップ 20) では、今後必要となる 8 つのキーファクターを以下のようにまとめている。

・発電装置の研究開発

·安定的な発展のための政策的体制

・適地選定と許認可のガイドライン

- 環境影響評価研究

・関連産業と連携したマーケット開拓

・経済財政支援策

·送電系統の統合化

・教育と労働者トレーニング

つまり、潮流発電が本当に実用化するためには多岐の課 題を克服する必要があるということである。その上で、彼 らは2030 年までを 3 つの Phase に分けて

·Phase-I デモ実験から試験プロジェクト $100 \mathrm{~kW} \sim 5 \mathrm{MW}$

·Phase-II 試験プロジェクトから小規模アレイ $5 \mathrm{MW} \sim 50 \mathrm{MW}$

· Phase-III 小規模アレイから商業規模スケール $50 \mathrm{MW} \sim 100 \mathrm{MW}$

という流れで、最終的に $15 \mathrm{GW}$ の設備容量を完成させると いうロードマップを示している。

このような課題と発展の道筋については、我が国にもそ のまま当てはまると思われる。我が国における当面の課題 としては、前述の実証実験フィールドの整備を行って多く の技術的な問題点を明確にし、それを克服することである が、それに加えて、海域の利用については漁民が最も大き な権利を有していることから「漁業」との連携、協調が大 前提となっている。さらに、発電コストに関しては、現在 のところ水中送電ケーブルが高価であるため、他の電力に 比べてコストが割高となることがはっきりしている。現在 のところ、潮流発電については、FIT（固定価格買取制度） の対象とはなっていないが、買取価格についてはこのよう な状況を考慮して設定されることを期待している。

\section{6. 結 論}

我が国の潮流発電の研究開発は、欧米・韓国から約 10 年 は遅れていると言わざるを得ないが、2013 年 4 月に発表さ れた「海洋基本計画」においては主要な取り組みとして「海 洋再生可能エネルギーの利用促進」が明記された。つまり、 今後は国策として推進することを決定したもので、潮流発 電についても強い追い風となろう。ただし、実用化に向け ては多くの技術的課題をクリアする必要がある。そのため に「実証実験フィールド」が必要であり、また、現在のと ころ海洋情報の量が圧倒的に不足しているので、今後、海 


$$
\text { スマートプロセス学会誌 第 } 3 \text { 巻 第 } 2 \text { 号 (2014 年 } 3 \text { 月) }
$$

洋情報のさらなる拡充が求められる。数值モデルなども駆 使して、高精度の海流・潮流マップの整備が求められる。

さらには、我が国固有の海洋環境に適する発電システム とメンテナンス法の確立が将来の永続的な運用には不可欠 である。例えば、付着生物による発電装置への污損は海域 の環境が要因であるが、コスト評価や環境影響評価とも関 係して事前調査が重要となろう。

\section{引用文献}

1) http://www.jamstec.go.jp/frcgc/jcope/htdocs/home.html

2) NEDO: 海洋エネルギーポテンシャルの把握に係る業務、平成 22 年度報告書、平成 23 年 3 月

3) http://www.ihi.co.jp/ihi/press/2011/2011-11-28/index.html

4) http://www.oist.jp/ja/news-center/photos/latest?page $=2$

5) ORPC 社 : http://www.orpc.co/

6) G. Kloos, C.A. Gonzalez and T.D. Finnigan: The bioSTREAMTM tidal current energy converter, Proc. of the 8th EWTEC, Uppsala, Sweden, (2009) 426-433

7) http://www.alstom.com/power/renewables/ocean-energy/tidalenergy/
8) Delta Stream: http://www.tidalenergyltd.com/

9) Pulse Tidal: http://pulsetidal.co.uk/

10) BlueWater: http://www.bluewater.com/new-energy/

11) TidalStream: http://www.tidalstream.co.uk/

12) Hammerfest : http://www.hammerfeststrom.com/

13) MCT: http://www.marineturbines.com/

14）木方靖二、塩野光弘：来島海峡におけるダリウス形水車によ る潮流発電、電気学会論文誌 D、112-D-6 (1992.6) 530-538.

15) http://www.kaiho.mlit.go.jp/syoukai/soshiki/soumu/seika/h12/ h12all.pdf “海上保安庁 潮流発電”

16）鳥井正志、大久保寛、山根信、相良啓太、関和市：直線翼鉛 直軸型潮流発電システムの応用、太陽/風力エネルギー講演 論文集、(2004) 73-76.

17) http://www.nova-ene.co.jp/

18) http://www.city.kitakyushu.lg.jp/kankyou/00200009.html

19) EMEC: http://www.emec.org.uk/

20) OCEAN RENEWABLE ENERGY COALITION: U.S. Marine and Hydrokinetic Renewable Energy Roadmap, Executive Summary, (2011.11) http://www.oceanrenewable.com/ 